\title{
Analysis of Physical \& Chemical Properties of Cotton- Jute Blended Denim After a Sustainable (Industrial Stone Enzyme) Wash
} \author{
Sagir Rakin ${ }^{4}$ \\ ${ }^{1}$ Department of Apparel Engineering, Bangladesh University of Textile, Bangladesh \\ ${ }^{2}$ Department of Textile Engineering, Mawlana Bhashani Science and Technology University, Bangladesh \\ ${ }^{3}$ Department of Textile Engineering, Green University of Bangladesh, Bangladesh \\ ${ }^{4}$ Textile Engineering Department, Bangladesh University of Business and Technology (BUBT), Bangladesh
}

Sazid Elahi' ${ }^{1}$, Md. Dulal Hosen²*, Mazedul Islam ${ }^{1}$, Zayedul Hasan², Md. Mazharul Helal ${ }^{3}$ and Md Saitham Al

*Corresponding author: Md.Dulal Hosen, Department of Textile Engineering, Mawlana Bhashani Science and Technology University (MBSTU), Tangail-1902, Bangladesh.
Received Date: June 28, 2019

Published Date: July 09, 2019

\begin{abstract}
Washing is one of the most important finishing treatments applied on apparels that have great usage to create special outlooks and improving the fashion. Technologically denim washing is the most important fashion element for clothing industry. The aim of this paper is to determine the effects of industrial stone enzyme wash on cotton-jute blended denim fabric. For this investigation, blended denim $(75 \%$ cotton \& $25 \%$ jute of total weight of fabric with twill $3 / 1$ weave construction) leg panels were chosen. The selected denim fabric has been processed by stone enzyme wash, in order to evaluate the washing effects on denim leg panel, changes of fabric specification (ends/inch, picks/inch), fabric tensile strength, GSM, shrinkage, color fastness and rubbing test results has been determined after enzyme wash. Then $\mathrm{pH}$ is measured, and SEM test done to check the microscopic changes on the fabric surface
\end{abstract}

Keywords: Denim fabric; Stone Enzyme Wash; Cotton-Jute blend; Bleach wash; Sustainable Wash

\section{Introduction}

In the modern world, the use of denim has spread all over the world. Using blended denim may open up a whole new sector in the readymade garments department. After making garments from solid color dyes or pigment printed fabric, the garments are washed. By washing, color \& outlook of the garments are modified. As a result, new outlook and appearance is produced in the garments, which is not possible in any other method. Moreover, due to washing, starch materials present in the garment are removed, as a result washed garments could be worn right after purchasing from the store. Denim made from Jute and cotton blend yarn is a relatively new process and by this project we hope to determine what the effect of enzyme wash is on blended denim fabric.

In this work, it is tested that how quality of the fabric is changed after going through Enzyme wash. As both cotton and jute are natural fibers and homegrown in our country, it would be a great asset for the country if it can be marketed and sold as a readymade garment. Denim is one of the world's oldest fabric's which is most commonly associated with jeans. Denim is very strong, stiff and hard-wearing fabrics [1]. Denim is twill weave fabric that uses colored warp and white weft yarn and used for jeans, work clothes and casual wear [2]. Denim wear has gained popularity all over the world. As a result, jeans wear is one the most prominent apparel items in the world [3]. The evolution of the denim market has led to the development of some unique and creative denim fabrics and opened new worlds of possibility for finishes [4].The birth of denim jeans is credited to the Bavarian-born businessman, Levi Strauss, who made his way to the Gold Rush in San Francisco nearly 150 years ago. Since then, the denim fabric has run the gamut from a basic work wear fabric to a fashion trend setter, it is one of the most fashionable items in the fashion and textile industry today and the original focus on durability and practicality has changed to fashion. Denim can provide the durability and different appearance effect for the garment when it is conducting the different denim garment, and most people wearing the denim garment. Deterioration in the denim fabric of the textile product is often important to the physical properties in deciding when the article has reached the end of it using life [5]. 
Industrial garments washing is one of the major processes followed in the textile sector. By industrial garments washing, dust, dirt and infectious materials can be removed from garments. For improving special look on garments as per fashion requirement, a variety of wash techniques can be followed [6]. For washing of denim garments, a range of treatment methods such as enzymatic treatment [7], bleaching treatment [8,9], acid treatment $[10,11]$, and Silicone treatment [12], are used widely. They all are aimed at new possible effects of fabric appearance. Particularly the dry finishing creates many effects on denim fabric; it will stimulate the customers to buy, and also it increases the market potential of the denim market [13]. Nowadays along with denim washing knit garments such as T-shirt, Polo shirt, and trouser, are washed by using different techniques as follows: enzymes wash, softener wash, Silicone wash, tie dye wash, pigment wash, caustic wash, etc. are used to create or enhance the physical and mechanical property changes $[14,15]$. Enzymes are important in regulating the chemical reactions that occur within all living organisms. Without enzymes, many of these reactions would not be able to take place at a perceptible rate [16]. Jute fibre is a bast fiber obtained from the bark of jute plant containing three main categories of chemical compounds namely cellulose (58 63\%), hemi-cellulose (20 24\%) and lignin (12 15\%), and some other small quantities of constituents like fats, pectin, aqueous extract. Jute fiber is composed of small units of cellulose surrounded and cemented together by lignin and hemicellulose [17]. Jute fiber conventionally is not used for producing wearable textile products as it has some shortcoming in regard to feel, stiffness, drape, coarseness, wash ability and abrasion [18]. Now a days, in jute sector, demand of diversified jute uses, and improved quality is increasing for the use in different areas namely floor coverings, household textiles, technical textiles, handicrafts, etc. [19]. Blending is a technique to overcome the poor characteristics of one fiber. It is the technique to combine fibers which emphasizes the good qualities and minimizes poor qualities of the fibers. It also makes the fabric manufacturing process economical. Jute-cotton blended yarn is one of the examples of it [20]. Blending jute with cotton fiber may be an acceptable way of jute diversification by which value added products can be produced. Jute fibers have several advantages like a lustrous golden appearance, high tenacity and good properties. Hence the techniques of blending and softening could have utilized to upgrade the quality of jute and thus form a new class of jute-based fabrics having an expanding market within and outside the country [21]. In the present work, a few characteristics of jute-cotton blended fabrics have been evaluated. Fabric produced from the blended yarn might have better characteristics than what could be obtained in a fabric produced from a single fiber. Any successful attempt to blend jute fiber with cotton would be a breakthrough in the field of textile [22]. The use of fabrics made from Jute-Cotton blended yarns would surely strength our economy by cutting a part of the cost incurred for importing cotton and enhancing the value addition due to locally produced cheaper jute as a raw material [23].

In garments industry, there are mainly two types of washing process for garments products. Those processes are wet washing process and dry washing process [24]. Here also wet washing process is divided by eight ways and the dry washing process is divided by five ways, according to the fabric quality and buyer requirements. But most common and applied wash in garment is normal wash, which is also known as detergent wash. In the wet washing process enzyme wash, stone wash and bleach wash are most popular to the buyer and the manufacturer. On the other hand, Potassium per magnet spray and hand scraping is common for dry washing process in the garments industry. Garments washing is being used as a novel process to modify the appearance to impart worn-out look and to improve the comfort ability of the garments, especially denim garments [25]. Enzyme washing of denim garments helps in bio-polishing and to fade the color of the denim to a desired degree depending on the processing time and conditions. Adding pumice stone with enzyme extend the degree of fading and adds special effect in the multi ply areas like different seams and hems [26]. Using pumice stone causes wear and tear of the garments and the machine surface .Enzymatic treatments have a lot of advantages over the stone washing but the stone has a different irregular effect on the garments which is very difficult to achieve with only enzyme. As only stone causes harm to the garments and machine, then using enzyme with the stone can bring the desired effect quickly with minimum harm to the garments and machine [27]. So, using enzyme and stone both in the same bath helps to achieve the required shape in comparatively short time with wear and tear of the garments within a tolerable range.

\section{Materials and Methods}

\section{Raw materials}

The following raw materials are used to complete the evaluation of this work:

- Jute-cotton blended denim fabric

- Chemicals: Chemicals used for the Enzyme wash are listed below-

- $\quad$ Desizing agent (Soda Ash)

- $\quad$ Anti-Back staining agent

- $\quad$ Neutral enzyme

- $\quad$ Bleaching agent $\left(\mathrm{KMnO}_{4}\right)$

- $\quad$ Neutralizing Agent (Hydroxyl Ammonium Sulphate)

- Garments Washing Machine

- Zanussi Hydro Extractor

- Opti-Dry Drying machine

- $\quad$ Electronic Crock Meter

- $\quad$ Fabric GSM Cutter

- $\quad$ Scanning Electron Microscope (SEM)

\section{Methods}

Method of experiment: Stone Enzyme wash is done on the denim leg panel. The processes parameters are given below: 


\section{Desizing}

- Desizing agent: 50gm

- Anti-Back staining agent: 50gm

- Temperature: $50^{\circ} \mathrm{C}$

- $\quad$ Time: $10 \mathrm{~min}$

- Water: 120 liters

- $\quad$ Fabric weight: 450gm (Approx.)

\section{Stone enzyme wash}

- $\quad$ Neutral Enzyme: 100gm

- $\quad$ Pumice stone: $3.5 \mathrm{~kg}$

- $\quad$ Anti-Back staining agent: 100gm

- Temperature: $45^{\circ} \mathrm{C}$

- $\quad \mathrm{P}^{\mathrm{H}}:$ 6-7

- $\quad$ Time: 15 minutes

- Water: 100 liters

\section{Bleach wash}

- $\quad$ Time: $10 \mathrm{~min}$

- Temperature: $40^{\circ} \mathrm{C}$

- P.H: $10-11$

- Water: 100 liters

- $\quad$ Bleaching agent: $\mathrm{KMnO}_{4}(6$ gm)

\section{Neutralization}

Hydroxyl Ammonium Sulphate is used for neutralizing.

\section{Hydro extraction}

Hydro-extraction is done for $1.5 \mathrm{~min}$ to extract all the excess water from the fabric.

\section{Dryer}

Steam drier is used to dry the fabric. Machine is run for 20 minutes.

The flowchart for the whole process is given below

\section{Desizing}

$$
\begin{gathered}
\text { Garments are loaded } \\
\downarrow \\
\text { Water is added (120 liter) } \\
\downarrow \\
\text { Machine started running } \\
\downarrow \\
50 \text { gm Soda Ash added }
\end{gathered}
$$$$
\downarrow
$$

50 gm Anti back staining agent added
Steam to raise temp $50^{\circ} \mathrm{C}$

$$
\downarrow
$$

Process time 10 minutes

$$
\begin{gathered}
\downarrow \\
\downarrow \text { Drop liquor } \\
\downarrow
\end{gathered}
$$

Wash down twice

\section{Stone Enzyme wash}

$$
\begin{gathered}
\text { Garments loading } \\
\downarrow \\
\text { Water is added (100 Liter) } \\
\downarrow \\
\text { Machine started running } \\
\downarrow \\
\text { 100gm Neutral Enzyme added } \\
\downarrow \\
100 \text { gm Anti back staining agent added } \\
\downarrow \\
\text { Steam to raise temp } 45^{\circ} \mathrm{C} \\
\downarrow \\
\text { Process time } 20 \text { minutes } \\
\downarrow \\
\text { Drop liquor }
\end{gathered}
$$

\section{Bleach wash}

$$
\begin{gathered}
\text { Water is added (100 Liter) } \\
\downarrow \\
\text { Machine started running } \\
\downarrow \\
\text { 6gm KMnO4 added } \\
\downarrow
\end{gathered}
$$

Steam to raise temp $40^{\circ} \mathrm{C}$

$$
\downarrow
$$

Process time 5 minutes

$$
\downarrow
$$

Drop liquor

\section{Neutralization}

Water is added (400 Lt)

$$
\downarrow
$$

Machine started running

$$
\downarrow
$$

Hydroxyl Ammonium Sulphate added

$$
\downarrow
$$

1 Kg Salt added

$$
\downarrow
$$

Steam to raise temp $50^{\circ} \mathrm{C}$

$$
\downarrow
$$

Process time 10 minutes

$$
\downarrow
$$

Check Shade

$$
\downarrow
$$

Drop the liquor 
5. Drying

$$
\begin{gathered}
\text { Garments are then taken out } \\
\downarrow \\
\text { Hydro extracted for } 1.5 \text { min } \\
\downarrow \\
\text { Send to dryer for } 20 \text { minutes }
\end{gathered}
$$

\section{Method of Testing \& Data Collection}

\section{EPI \& PPI}

In order to measure EPI and PPI, 3 samples are taken. 1 sq. inch counting glass is used to measure the number of yarns in both warp and weft direction. The number of warp yarns per sq. inch is EPI and the number of weft yarns per sq. inch is PPI. The average of 3 samples are taken before and after wash.

\section{Shrinkage}

A square of 10 " $\times 10$ " is marked on the fabric samples using permanent marker before washing. The length and width of the square is measured after washing. The difference is used to measure the shrinkage according to AATCC test method ASTM D 2724, BS 4931.

\section{GSM Test}

Fabric is cut from the leg panel using the GSM Cutter and the cut piece is measured using an electric balance. Then the measured weight is multiplied by 100 to get the value of GSM. The method used was ASTM D 3776.

\section{Tensile strength} 5034

Method: US Standard Grab test method according to ASTMD -

Dimension of sample $-6 " \times 4 "$

Gauge length - 75mm

Strength is measured before and after wash to quantify the strength loss.

\section{Rubbing test}

Method- Crocking (AATCC) Machine- Crock meter

Sample dimensions- $130 \mathrm{~mm} \times 50 \mathrm{~mm}$

Cycle- 10

Rubbing test is done both in wet and dry conditions.

\section{Color fastness to wash}

Method- AATCC $612(A)$

Sample dimensions- 6" x 2"

Washing parameters:

- $\quad$ Temperature $-49^{\circ} \mathrm{C}$

- $\quad$ Time $-45 \mathrm{~min}$

- $\quad \mathrm{RPM}-40$

- $\quad$ Steel Ball - 50 pcs
- Dia of steel ball - $6 \mathrm{~mm}$

\section{Process Flowchart of washing}

1-liter distilled water taken

$\downarrow$

150 gm AATCC detergent added (without OBA)

$\downarrow$

Making solution by stirring

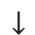

Solution for specimen $(150 \mathrm{ml})$

$\downarrow$

Fabric is placed into the steel container

$\downarrow$

Container is placed into the Laundry meter

$\downarrow$

Start the machine

$\downarrow$

Rotate for 45 minutes

$\downarrow$

Washing (cooling)

$\downarrow$

Drying (15-20 mins)

Then the fabric is taken under the light box to match with grey scale to determine the color fastness to wash.

\section{pH test}

Machine used - Mettler Toledo pH meter

$250 \mathrm{ml}$ distilled water taken and boiled for 10 minutes. Then $10 \mathrm{gm}$ sample is cut in small pieces in 2 batches and added to the water one batch at a time and kept under water for 10 minutes. The temperature has to be moderate and the sample is cooled after taking out of the water.

\section{SEM test}

The morphological value of the jute-cotton denim fabric was examined by scanning electron microscopy (SEM).

Brand: Hitachi

Model: S $3400 \mathrm{~N}$

Origin: Japan

\section{Results and Discussion}

\section{Results}

EPI \& PPI

\section{Shrinkage}

- Initial length - 10 inches

- Initial width - 10 inches

- $\quad$ After wash length - 9.5 inches

- $\quad$ After wash width -9.3 inches

So, Length wise shrinkage $=\frac{10-9.5}{10} \times 100=5 \%$ 
So, Width wise shrinkage $=\frac{10-9.3}{10} \times 100=7 \%$

\section{GSM Test}

\section{Rubbing Test}

Grey scale results for the rubbing test are-

- $\quad$ Dry test -4.5

- Wet test -2

\section{Tensile Strength test}

\subsubsection{Color fastness to wash}

Grey scale results for the color fastness test is:

Bleeding - 3.5

\section{Staining to Multifiber}

- $\quad$ Acetate -3.5

- $\quad$ Cotton -3.0
- $\quad$ Nylon - 3.5

- $\quad$ Polyester -4.5

- $\quad$ Acrylic - 4.5

- $\quad$ Wool -3.5

pH test

pH was tested using two samples after wash

- $\quad$ Sample-1 pH: 6.4

- $\quad$ Sample-2 pH: 6.5

\section{SEM Test}

\section{Discussion}

\section{EPI \& PPI}

From the Figure $1 \&$ Figure 2 it can see that both EPI and PPI increased after the enzyme wash. That means the number of warp and weft yarn was increased inside a specific area.

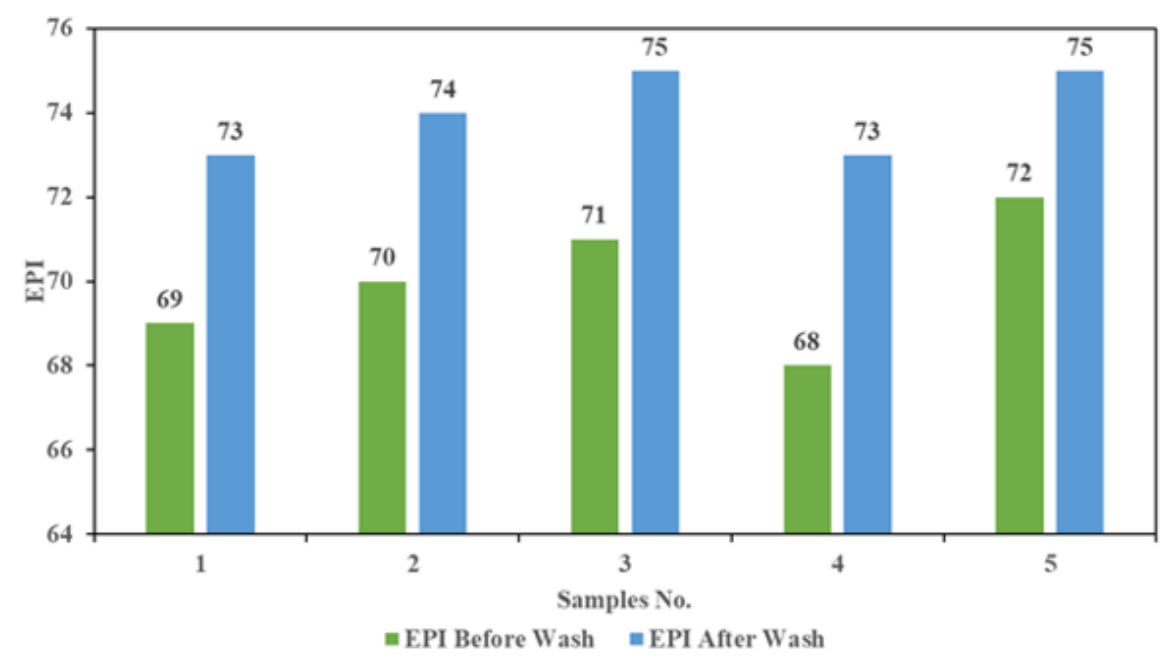

Figure 1: EPI before and after wash.

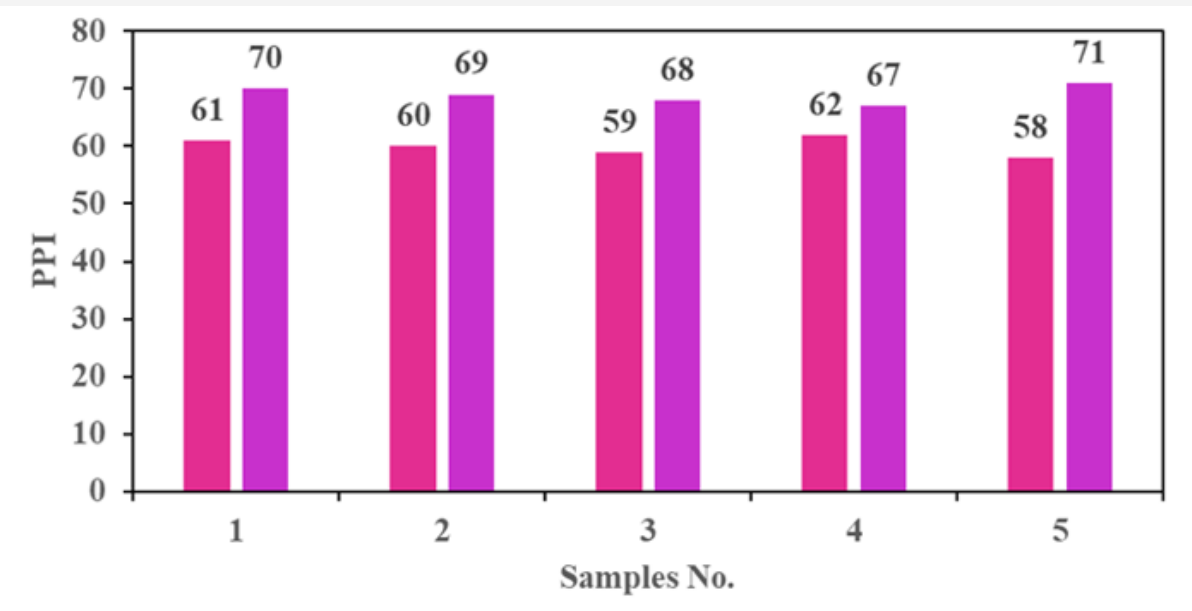

nPI Before Wash $\quad$ PPI After Wash

Figure 2: PPI before and after wash. 


\section{Shrinkage}

From the shrinkage test done on 10 " x 10 " sample, it found out both lengthwise and widthwise shrinkage occurred in the fabric. But the shrinkage amount was overall lower than regular cotton denim fabric. Also, width wise shrinkage was higher than length wise shrinkage.

\section{GSM Test}

From the GSM test, here it saw that the GSM of the fabric increased from 340 to $348 \mathrm{gm} / \mathrm{m}^{2}$. Here, GSM is increased like regular cotton denim.

\section{Rubbing Test}

Here the crock meter is used to test the rubbing fastness on the fabric in both dry and wet condition. The fabric fared very well in the dry staining test scoring 4.5 on the gray scale. But the result of the wet test was not up to standard as it was 2 on the gray scale meaning there was heavy staining on the crock meter fabric (Figures 3-5).

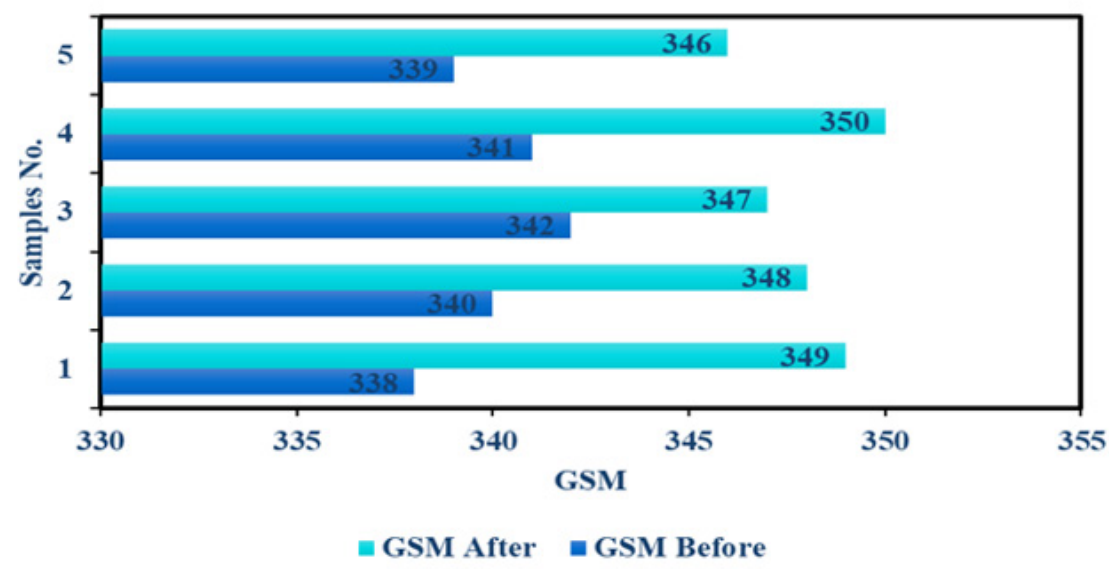

Figure 3: GSM before and after wash.

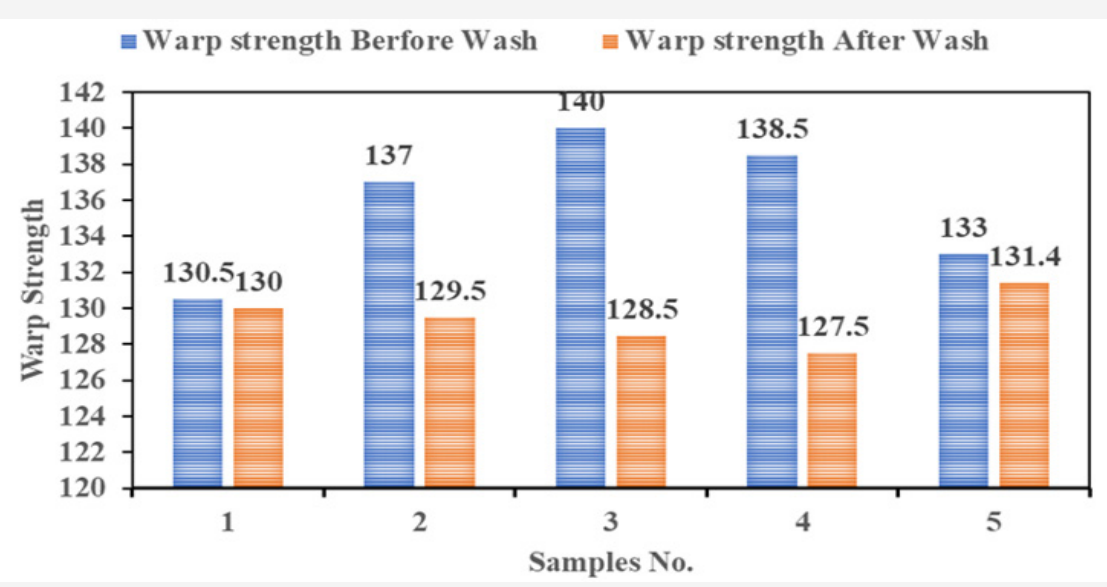

Figure 4: Warp strength before \& after wash.

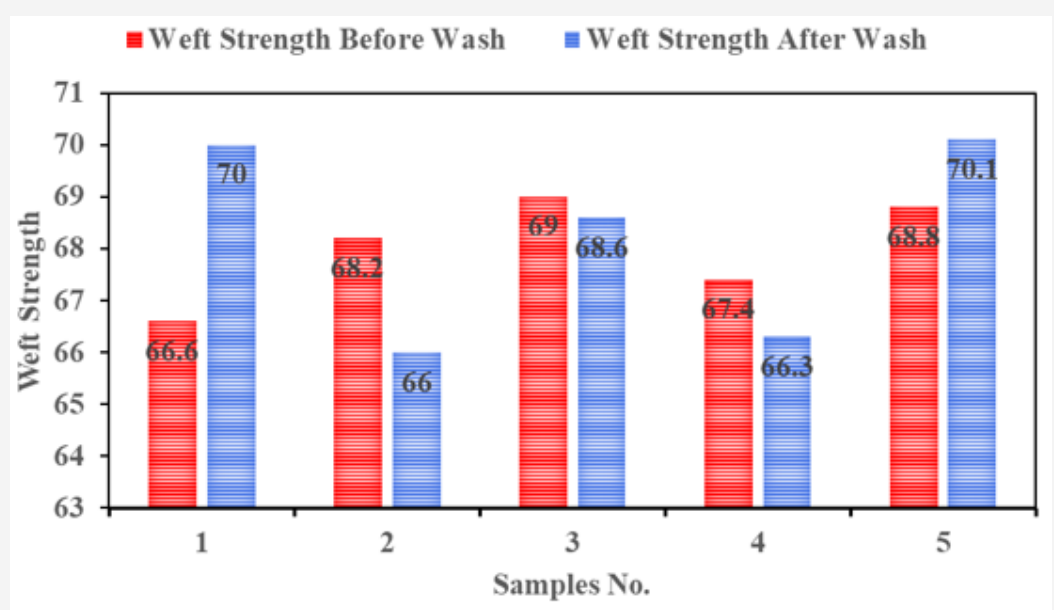

Figure 5: Weft strength before \& after wash. 


\section{Tensile Strength test}

Here checked both the warp way strength and weft way strength before and after wash. In both directions, the strength went down after the enzyme wash. The fabric lost considerable amount of strength after the wash.

\section{Color fastness to wash}

After washing the fabric under laboratory condition, we used the gray scale to measure the color fastness to wash where it scored 3.5 out of 5 . That means, the fabric shows considerable performance to color fastness to wash.

\section{pH test}

We checked the $\mathrm{pH}$ of the fabric surface using the $\mathrm{pH}$ meter and the result was slightly different for the two samples we used. But the variation was 0.1 and in both cases the fabric was slightly acidic at 6.4 and 6.5 .

\section{SEM Test}

After washing the cotton-denim fabric with Stone Enzyme wash the Fabric was looking more attractive and here its molecules are looking more compact (Figures 6-8).

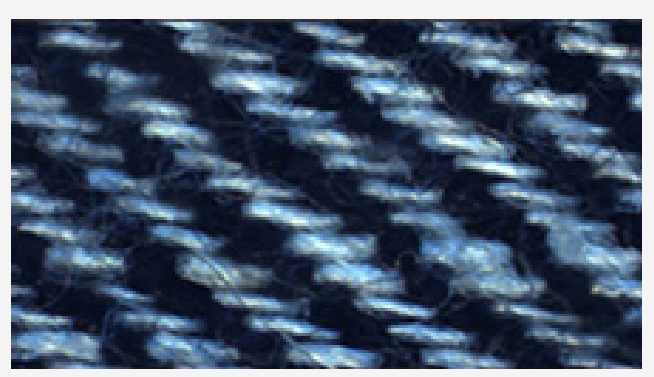

Figure 6: Raw garments back.

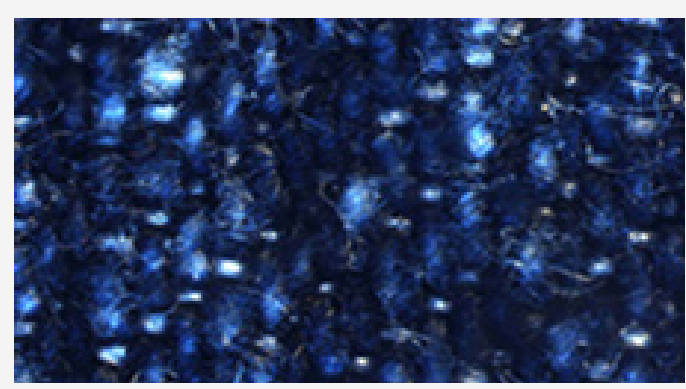

Figure 7: Stone enzyme face.

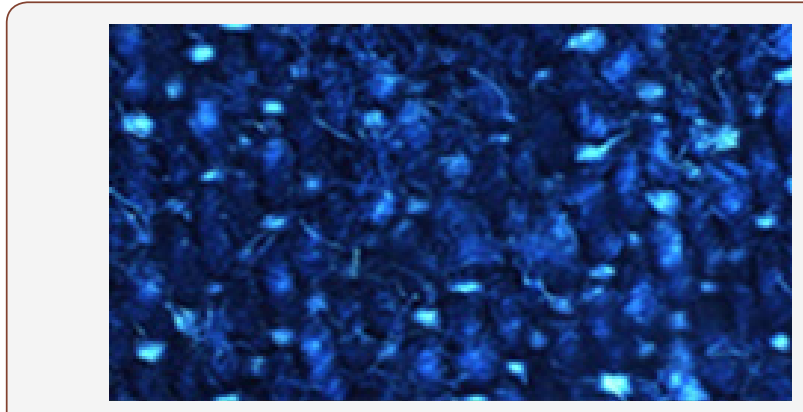

Figure 8: Stone enzyme back.

\section{Conclusion}

Through this work it was the Analysis of Physical \& Chemical Properties of Cotton Jute Blended Denim after a Sustainable (Industrial Stone Enzyme) Wash. The EPI and PPI, GSM was increased after washing process. In this work the warp strength decreased but it was not too much. On the other hand, the weft strength was increased a little bit. By this work we have found a new shade that will be helpful to increase the beauty of the denim. If this research can be applied in textile production purposes it will be more beneficial to the whole world. So, it can be a new revolution in the world of Denim.

\section{Acknowledgment}

The authors wish to thank Government Jute Denim Project of Bangladesh, Bangladesh University of Textile (BUTEX) and Mawlana Bhashani Science and Technology University (MBSTU) for the financial support for this work.

\section{Conflict of Interest}

No conflict of interest.

\section{References}

1. Kashem MA (2008) Garments Merchandising, $1^{\text {st }} e d n$, Lucky one trader: 69-71.

2. Razzaque MA (2004) Garments \& Textile Merchandising, $1^{\text {st }}$ edn, Dhaka, Popular Publication: 223-226.

3. Khan ME (2004) Technology of Denim Manufacturing, 1st Edition, Books Fair Publications, Dhaka: 283-284.

4. Yoon MY (2005) Denim finishing with Enzymes of Genecer International, USA Dyer International: 11.

5. Webster J, Laing RM (1998) Fibres to Finished Fabric proceedings.

6. Mondal MI, Rahman Khan MM (2014) Characterization and Process Optimization of Indigo Dyed Cotton Denim Garments by Enzymatic Wash. Fashion and Textiles 1: 1-12.

7. Sarkar J, Khalil E, Solaiman M (2014) Effect of Enzyme Washing Combined with Pumice Stone on the Physical, Mechanical and Color Properties of Denim Garments. International Journal of Research in Advent Technology 2(9): 65- 68.

8. Sarkar J, Khalil E (2014) Effect of Industrial Bleach Wash and Softening on the Physical, Mechanical and Color Properties of Denim Garments. IOSR Journal of Polymer and Textile Engineering 1(3): 46-49.

9. Khan MM, Mondal MI, Uddin MZ (2011) Effect of Bleach Wash on the Physical and Mechanical Properties of Denim Garments. International Conference on Mechanical Engineering.

10. Haq UN, Khan MM (2014) Technology of Acid Wash on Woven Denim Apparel with Damp Pumice Stone.

11. Khalil E (2015) Effect of Processing Time and Concentration of Potassium Permanganate on Physico-Mechanical Properties of Denim Jeans during Stone Washing. Science Innovation 3: 68-71.

12. Kashem MA (2008) Garments Merchandising, (1 ${ }^{\text {st }}$ edn), Lucky one trader.

13. Khalil E, Islam MM (2015) Wrinkle Finish on Denim by Resin Treatment: A Review. AASCIT Communication: 82-87.

14. Khalil E, Sarkar J, Rahman M, Solaiman M (2014) Influence of Enzyme and Silicone Wash on the Physico Mechanical Properties of NonDenim Twill Garments. International Journal of Scientific \& Technology Research 3(10): 231-233. 
15. Gokarneshan N, Durairaj C, Krishnamurthy P, Shanmugasundaram S, Subhash R, et al. (2009) Chemical Finishing and Washing of Knit Wear.

16. Excerpt from the Encyclopedia Britannica.

17. Pan NC, Day A, Mahalanabis KK (1999) Chemical Composition of Jute and its Estimation; Man-made Textiles In India 9: 467-473.

18. Azad Md AK, Jafrin S (2009) Study on the effect of size material on JuteCotton union fabric. Daffodil International University Journal of Science and Technology 4(1): 42-44.

19. Sengupta S, Debnath S (2012) Studies on jute based ternary blended yarns. Indian Journal of Fibre and Textile Research 37: 217-223.

20. Bhardwaj S, Juneja S (2013) Performance of Jute Viscose/Polyester and Cotton Blended: Yarns for Apparel Use. Stud Home Com Sci 6(1): 33-38.

21. Charankar SP, Gupta M, Bhanuben MN (2007) Growing importance of Cotton blends in apparel market. Journal of the Textile Association: 201210.
22. Salam MA, Farouqui FI, Mondal Md IH (2007) A Study on Sulphonated Jute- cotton Blended Yarn and Fabrics and their Characteristics Bangladesh J Sci Ind Res 42(3): 281-286.

23. Ahmed Ullah AN (2012) An investigationon on the effect of machine parameters of spinning machine on the physical properties of blended yarn, PhD Thesis, Jahangirnagar University, Dhaka, Bangladesh.

24. Different Types of Garments Wash.

25. Enzymes used in Textile.

26. Enzyme wash.

27. Enzyme Wash | Objects of Enzyme Wash | Enzyme Washing Process. 